Preliminary simulations of planned experiments to study the impact of trace gases on the capacity of the Weyburn-Midale field to store carbon dioxide

S. Carroll, Y. Hao

November 19, 2009 
This document was prepared as an account of work sponsored by an agency of the United States government. Neither the United States government nor Lawrence Livermore National Security, LLC, nor any of their employees makes any warranty, expressed or implied, or assumes any legal liability or responsibility for the accuracy, completeness, or usefulness of any information, apparatus, product, or process disclosed, or represents that its use would not infringe privately owned rights. Reference herein to any specific commercial product, process, or service by trade name, trademark, manufacturer, or otherwise does not necessarily constitute or imply its endorsement, recommendation, or favoring by the United States government or Lawrence Livermore National Security, LLC. The views and opinions of authors expressed herein do not necessarily state or reflect those of the United States government or Lawrence Livermore National Security, LLC, and shall not be used for advertising or product endorsement purposes.

This work performed under the auspices of the U.S. Department of Energy by Lawrence Livermore National Laboratory under Contract DE-AC52-07NA27344. 


\title{
Preliminary simulations of planned experiments to study the impact of trace gases on the capacity of the Weyburn- Midale field to store carbon dioxide
}

\author{
Susan Carroll and Yue Hao \\ Lawrence Livermore National Laboratory
}

\section{Background}

The $\mathrm{CO}_{2}$ stream injecting into the Weyburn-Midale field can be generally classified as a reducing stream with residual $\mathrm{H}_{2} \mathrm{~S}$ and low-molecular weight hydrocarbons. The composition of the $\mathrm{CO}_{2}$ gas stream from the Dakota Gasification Company is reported to be $95 \% \mathrm{CO}_{2}, 4 \%$ hydrocarbons, and $1 \%$ $\mathrm{H}_{2} \mathrm{~S}$ by volume (Huxley 2006). In addition to the $\mathrm{H}_{2} \mathrm{~S}$ introduced at the injection wells, significant concentrations of $\mathrm{H}_{2} \mathrm{~S}$ are thought to have been produced in-situ by sulfate reducing bacteria from previous water floods for enhanced oil production (Bailey et al., 1973; Emberley et al., 2005, Huxley 2006). Produced gas compositions range in $\mathrm{H}_{2} \mathrm{~S}$ concentrations from 1 to 6 volume percent. The produced gas, including the trace impurities, is re-injected into the field. Although there is no evidence for inorganic reduction of $\mathrm{SO}_{4}{ }^{2-}$ to $\mathrm{H}_{2} \mathrm{~S}$ at the WeyburnMidale field, Sitchler and Kazuba (2009) suggest that $\mathrm{SO}_{4}{ }^{2-}$ can be inorganically reduced to elemental sulfur in highly reducing environments based on a natural analog study of the Madison Formation in Wyoming. They propose that elevated concentrations of $\mathrm{CO}_{2}$ dissolve anhydrite to produce the sulfate that is then reduced.

Oxidizing $\mathrm{CO}_{2}$ streams with residual $\mathrm{O}_{2}$ and $\mathrm{SO}_{2}$ typical of streams captured from oxyfuel and post combustion processes are not presently an issue at the Weyburn-Midale field. However it is possible that the oxidizing $\mathrm{CO}_{2}$ streams may be injected in the future in carbonate reservoirs similar to the Weyburn-Midale field.

To date there are few modeling and experimental studies that have explored the impact of impurity gases in $\mathrm{CO}_{2}$ streams targeted for geologic storage (Gale 2009). Jacquemet et al (2009) reviewed select geochemical modeling studies that explored the impact of $\mathrm{SO}_{2}$ and $\mathrm{H}_{2} \mathrm{~S}$ impurities in the waste streams (Gunter et al., 2000, Knauss et al., 2005, Xu et al., 2007). These studies collectively show that $\mathrm{SO}_{2}$ significantly reduces the $\mathrm{pH}$ when oxidized to $\mathrm{H}_{2} \mathrm{SO}_{4}$ causing enhanced dissolution of carbonate minerals and some sulfate mineral precipitation. Low $\mathrm{pH}$ results in higher mineral solubility and faster dissolution 
rates and is thought to enhance porosity and permeability near the injection well when trace amounts of $\mathrm{SO}_{2}$ is injected with $\mathrm{CO}_{2}$.

The impact of $\mathrm{H}_{2} \mathrm{~S}$ on storage reservoir performance appears to more subtle. Knauss et al (2005) report no significant impacts of injection of $\mathrm{CO}_{2}$ gas

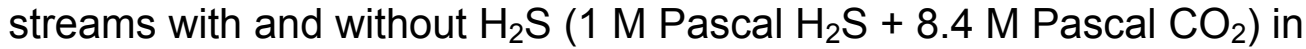
simulations of $\mathrm{CO}_{2}$ storage in the Frio sandstone formation. Geochemical reactions for $\mathrm{H}_{2} \mathrm{~S}$ impurities include enhance field alkalinity and reaction with iron bearing minerals that may delay breakthrough of $\mathrm{H}_{2} \mathrm{~S}$ relative to $\mathrm{CO}_{2}$. Emberley et al. (2005) report that half of the alkalinity measured at monitoring wells at the Weyburn-Midale field is due to $\mathrm{HS}^{-}$. Schoonen and $\mathrm{Xu}(2004)$ report that $\mathrm{H}_{2} \mathrm{~S}$ can be sequestered as pyrite in sandstones and carbonates by dissolving iron hydroxides and iron-bearing clays. Similarly, Gunter et al (2000) propose the that siderite converts to iron sulfides when it is reacted with $\mathrm{H}_{2} \mathrm{~S}$. The geochemical reactions between $\mathrm{H}_{2} \mathrm{~S}$ and iron bearing minerals together with the high solubility of $\mathrm{H}_{2} \mathrm{~S}$ relative to $\mathrm{CO}_{2}$ may contribute to the delayed break though of $\mathrm{H}_{2} \mathrm{~S}$ in experiments.

A few core flood experiments have shown that the injection of supercritical $\mathrm{CO}_{2}$ into carbonate aquifers has the potential to significantly alter the porosity in the absence of trace gases such as $\mathrm{SO}_{2}$ and $\mathrm{H}_{2} \mathrm{~S}$. Luquot and Gouze (2009) documented a $2 \%$ porosity increase in carbonate cores when rock-water interactions were transport limited and solution concentrations were closer to equilibrium and a $4 \%$ porosity increase when rock-water interactions were reaction limited and solution compositions were further from equilibrium. Similarly Le Guen et al (2007) used x-ray micro-tomography and geochemistry to show that porosity significantly increases when reacted with pure $\mathrm{CO}_{2}$. While both of these studies nicely illustrate the relationship between reaction kinetics, thermodynamics, and porosity changes using x-ray micro-tomography, actual changes in a reservoir may be significantly lower because the input brines used in these studies were significantly dilute and below mineral carbonate saturation.

\section{Report Objective}

The objective of the simulations reported below was to explore viable experimental parameters for $\mathrm{CO} 2$ core flood experiments designed to investigate the impact of $\mathrm{CO} 2$ on porosity and permeability in the Weyburn-Midale storage reservoir. We describe the simulation results for core flood experiments in which formation waters that are equilibrated with supercritical $\mathrm{CO}_{2}$ at $60^{\circ} \mathrm{C}$ and $14.7 \mathrm{M}$ Pascals react with three different flow units within the Midale formation.

\section{Approach}

The numerical reactive-transport simulations were performed using the Nonisothermal Unsaturated-Saturated Flow and Transport code, NUFT (Nitao 1998). The NUFT code is a highly flexible software package for modeling multiphase, multi-component heat and mass flow and reactive transport in unsaturated and saturated porous media. An integrated finite-difference spatial discretization scheme is used to solve mass and energy balance equations in 
both flow and reactive transport models. The resulting nonlinear equations are solved by the Newton-Raphson method. The NUFT code is capable of running on PCs, workstations, and major parallel processing platforms. Some of the application areas include: nuclear waste disposal, $\mathrm{CO}_{2}$ sequestration, groundwater remediation, and subsurface hydrocarbon production (Buscheck et al., 2003; Carroll et al., 2008; Glassley et al., 2003; Johnson et al., 2004, 2005).

Our 1-D radial reactive transport model of the core flood experiments is based on geochemical and physical characteristics reported for the Midale Marly (M3), Midale Vuggy intershoal (V1) and shoal (V6) flow units. We chose to study the porosity evolution using these three units because their differences in initial mineral abundance, porosity, and permeability. The mineralogy for these units is shown in Table 1 and described in more detail in Durocher et al. (2003). Briefly, the Midale Marly (M3) has a much lower abundance of calcite relative to dolomite than flow units V1 and V6 from the Midale Vuggy flow unit. In addition to these major differences in mineralogy, the $\mathrm{V} 6$ flow unit is 5 to 25 times more permeable than the M3 or V1 flow units. Porosity for the flow units range from 10 to $26 \%$.

\begin{tabular}{lrrr}
\hline \multicolumn{3}{c}{ Table 1 (IEA Weyburn CO2 Monitoring and Storage Project, Subtask 31. } \\
Reservoir (Baseline) Mineralogy; Final report, & Durocher et al., 2003). \\
\hline wt \% & M3 & V1 & V6 \\
Calcite & 21.8 & 82.3 & 68.8 \\
Dolomite & 62.7 & 11.6 & 14.6 \\
Anhydrite & 5.2 & 2.8 & 12.8 \\
Quartz & 4.6 & 1.5 & 1.8 \\
K-feldspar & 3.5 & 0.9 & 0.5 \\
Plagioclase & 1.3 & 0.6 & 0.3 \\
Illite & 0.7 & 0.3 & 0.2 \\
Kaolinte & 0.2 & 0 & 0.9 \\
Anatase & 0.1 & 0 & 0 \\
Apatite & 0 & 0 & 0 \\
\multicolumn{4}{c}{} \\
Total & 100.1 & 100 & 99.9 \\
Porosity \% & 26 & 10 & 15 \\
Perm MD & 10 & 3 & 50 \\
Note* Report refers to trace amounts of pyrite and Appendix B shows \\
between 0 and 1 wt\% Fe2O3 in dolomite.
\end{tabular}

In our simulations, the reservoir brine is generated by equilibrating a $1 \mathrm{~m}$ $\mathrm{NaCl}$ brine with the flow unit mineralogy at $60^{\circ} \mathrm{C}$ and $14.7 \mathrm{M}$ Pascals using the EQ3/6 geochemical speciation code and the "shv" thermodynamic database to correct for pressure effects (Wolery 1992a, Johnson et al., 1992). The reservoir brine is then equilibrated with supercritical $\mathrm{CO}_{2}$ using a $\mathrm{fO}_{\mathrm{CO}}$ corrected for temperature and pressure (Span and Wagner, 1996). Chemical compositions of the reservoir brine and $\mathrm{CO}_{2}$-flood brine are shown in Table 2. The $\mathrm{CO}_{2}$-brine is then injected into a core with $r=7.5 \mathrm{~mm}$ and $\mathrm{I}=30 \mathrm{~mm}$ assuming homogeneous mineral distribution, porosity, and permeability for the flow units listed in Table 1. Changes in solution and gas chemistry, mineral abundance, and porosity are then tracked over a 30-day period. 
Table 2. Chemical composition of the $\mathrm{CO}_{2}$-equilibrated brine for the WeyburnMidale storage site.

\begin{tabular}{ccc}
\hline & This Study (molal) & Luquot and Gouze (2009) (molar) \\
\hline $\mathrm{T}^{\circ} \mathrm{C}$ & 60 & 100 \\
$\mathrm{pH}$ & 3.64 & 3.21 \\
$f_{\mathrm{CO} 2}$ & 80.4 & 100 \\
$f_{\mathrm{H} 2 \mathrm{~S}}$ & $7 \times 10^{-2}$ & \\
$\mathrm{Al}$ & $1.65 \times 10^{-8}$ & \\
$\mathrm{Ca}$ & $3.17 \times 10^{-2}$ & $8.25 \times 10^{-3}$ \\
$\mathrm{Cl}$ & 1.00 & 1.00 \\
$\mathrm{Fe}$ & $3.03 \times 10^{-15}$ & \\
$\mathrm{HCO}_{3}$ & 0.89 & 0.8 \\
$\mathrm{~K}$ & $1.20 \times 10^{-2}$ & $1.6 \times 10^{-4}$ \\
$\mathrm{Mg}$ & $1.05 \times 10^{-3}$ & 1.00 \\
$\mathrm{Na}$ & 1.00 & \\
$\mathrm{SO}_{4}$ & $3.67 \times 10^{-2}$ & \\
$\mathrm{SiO}_{2}(\mathrm{aq})$ & $3.59 \times 10^{-4}$ & \\
$\mathrm{HS}$ & $3.00 \times 10^{-3}$ & \\
\hline
\end{tabular}

In the reactive transport modeling, mineral-brine interaction was modeled using explicit kinetics instead of assuming partial equilibrium as in the EQ3/6 reaction-path calculation. Rates of interaction of a mineral with the brine were described by an equation of the form:

$$
\frac{d n}{d t}=-S k_{298.15 K} e^{-E / R(T-298.15)}\left(1-\left[\frac{Q}{K}\right]\right)
$$

where $n$ is the number of moles of the mineral, $t$ is time (s), $k$ is the rate constant for the mineral $\left(\mathrm{mol}-\mathrm{m}^{2}-\mathrm{s}^{-1}\right)$ at $298.15 \mathrm{~K}, S$ is the active surface area for the mineral $\left(\mathrm{m}^{2}\right), \mathrm{E}$ is the activation energy for the mineral $\left(\mathrm{kJ}-\mathrm{mol}^{-1}\right), T$ is the absolute temperature, $R$ is the gas constant, $K$ is the equilibrium constant for the mineral, and $Q$ is the corresponding activity product. Here $Q=K$ implies equilibrium, $Q<K$ implies undersaturation (and dissolution), and $Q>K$ implies supersaturation (and precipitation). The rate equation was used to describe both dissolution and precipitation, with whichever process being determined by the relationship between $Q$ and $K$. Note that a negative value of $d n / d t$ indicates dissolution. The rate constants and activation energies used in this study are shown in Table 3. Dolomite and K-feldspar were not allowed to precipitate in this model.

Table 3. Kinetic rate constants for dissolution/precipitation

\begin{tabular}{llll}
\hline Mineral & $\log \mathbf{k}^{*}$ & $\mathbf{E}^{* *}$ & Source \\
\hline Calcite & -5.81 & 23.5 & Palandri and Kharaka (2004) \\
Dolomite & -7.53 & 52.2 & Palandri and Kharaka (2004) \\
Magnesite & -9.34 & 23.5 & Palandri and Kharaka (2004) \\
Anhydrite & -3.19 & 14.3 & Palandri and Kharaka (2004) \\
\hline
\end{tabular}




\begin{tabular}{|c|c|c|c|}
\hline Quartz & -13.99 & 87.7 & Johnson et al. (2004) \\
\hline K-feldspar & -9.75 & 51.7 & Johnson et al. (2004) \\
\hline Muscovite/Illite & -13.0 & 22.0 & Johnson et al. (2004) \\
\hline Albite & -12.0 & 67.82 & Blumm and Lasaga (1995) \\
\hline Kaolinite & -12.4 & 29.0 & Johnson et al. (2004) \\
\hline \multicolumn{4}{|c|}{$\begin{array}{l}\text { *dissolution rate constant at } 298.15^{\circ} \mathrm{K} \text {, consistent with units of } \mathrm{mol}-\mathrm{m}^{2}-\mathrm{s}^{-1} \\
{ }^{* *} \text { activation energy, } \mathrm{kJ}^{-1} \mathrm{~mol}^{-1}\end{array}$} \\
\hline
\end{tabular}

\section{Results and Discussion}

Figures 1-6 show the simulation results as the $\mathrm{CO}_{2}$-equilibrated reservoir brine reacts with the Midale Marly and Vuggy flow units as a function of volume $\%$ anhydrite, calcite, dolomite, and porosity, as well as anhydrite, calcite, and dolomite saturation, and $\mathrm{pH}$. Net porosity is enhanced in all cores because the volume of calcite and dolomite dissolved by the acid brine is not fully compensated by the volume of anhydrite precipitated. In all cores, a chromatographic sequence is observed for the volume abundance of calcite, dolomite, and anhydrite that is related to mineral reaction kinetics. Calcite volume percent decreases first, followed by a decrease in dolomite simply because calcite dissolution rates are about two orders of magnitude greater than dolomite dissolution rates. Anhydrite abundance exhibits an inverse overprint on carbonate abundance curves, as the dissolved calcium from the carbonate minerals is partially precipitated as anhydrite. The dissolved sulfate for anhydrite precipitation is from the input solution. Anhydrite reaction rates are so fast that only small deviations from saturation are observed. Mineral abundance of silicate minerals are not shown here because low reaction rates and/or low mineral abundance lead to minimal changes in net porosity within the flow units. These phase may be much more important when we assess the role of trace gases within the storage formation.

The enhanced porosity zone increases with increased reaction time and flow rate, because more carbonate minerals dissolve to neutralize of a larger amount of the $\mathrm{CO}_{2}$-rich brine. The simulations show the most extensive porosity changes because they are designed to simulate reaction front between $\mathrm{CO}_{2}$ plume, the reservoir brine, and the formation mineralogy. The $\mathrm{CO}_{2}$-equilibrated brine is initially $\mathrm{pH} 3.6$ and undersaturated with respect to carbonate minerals. Thus, carbonate mineral dissolution proceeds until the downstream brine is equilibrated with calcite and anhydrite with a $\mathrm{pH}=4.8$. The simulations predict significant porosity changes that may damage the core if the flow rate is too fast or the reaction period too long.

In the sections below we compare porosity evolution for flow rates equal to 0.01 and $0.1 \mathrm{ml} / \mathrm{min}$ after one and five days of reaction along the length of the core. Additional simulations results are shown from 0 to 30 days of reaction but these time scales are not discussed here.

\section{Midale Marly (M3)}


Flow Rate $0.01 \mathrm{ml} / \mathrm{min}$. Reaction of the Midale Marly flow unit with $\mathrm{CO}_{2}$-rich brine for one day results in an increase in the porosity from its initial value of $26 \%$ to $39 \%$ at the inlet. Porosity evolution over distance results from calcite dissolution (up to $17 \mathrm{vol} \%$ ), dolomite dissolution (4 vol \%), and anhydrite precipitation (up to $8 \mathrm{vol} \%$ ). Beyond $1.5 \mathrm{~mm}$ of the inlet no change in porosity ocurrs because pore fluids are saturated with respect to calcite and anhydrite and supersaturated with respect to dolomite (dolomite is not allowed to precipitate in the model) as the fluid moves along the length of the core. The final acidity of the brine is near $\mathrm{pH} 4.8$ and is buffered by calcite saturation. Increasing the reaction time to five days results in greater enhanced porosity. Porosity increases from its initial value of $26 \%$ to $66 \%$ at the inlet. Enhanced porosity results from calcite dissolution (up to $17 \mathrm{vol} \%$ ) and dolomite dissolution (up to $40 \mathrm{vol} \%$ ) and anhydrite precipitation (up to $17 \mathrm{vol} \%$ ). Beyond $2.5 \mathrm{~mm}$ of the inlet no change in porosity is seen because pore fluids are saturated with respect to calcite and anhydrite and supersaturated with respect to dolomite (dolomite is not allowed to precipitate in the model) as the fluid moves along the length of the core. The final acidity of the brine is near $\mathrm{pH} 4.8$ and is buffered by calcite saturation. Extending the reaction out to 30 days yields significant changes in porosity that may compromise the integrity of the core during the experiment.
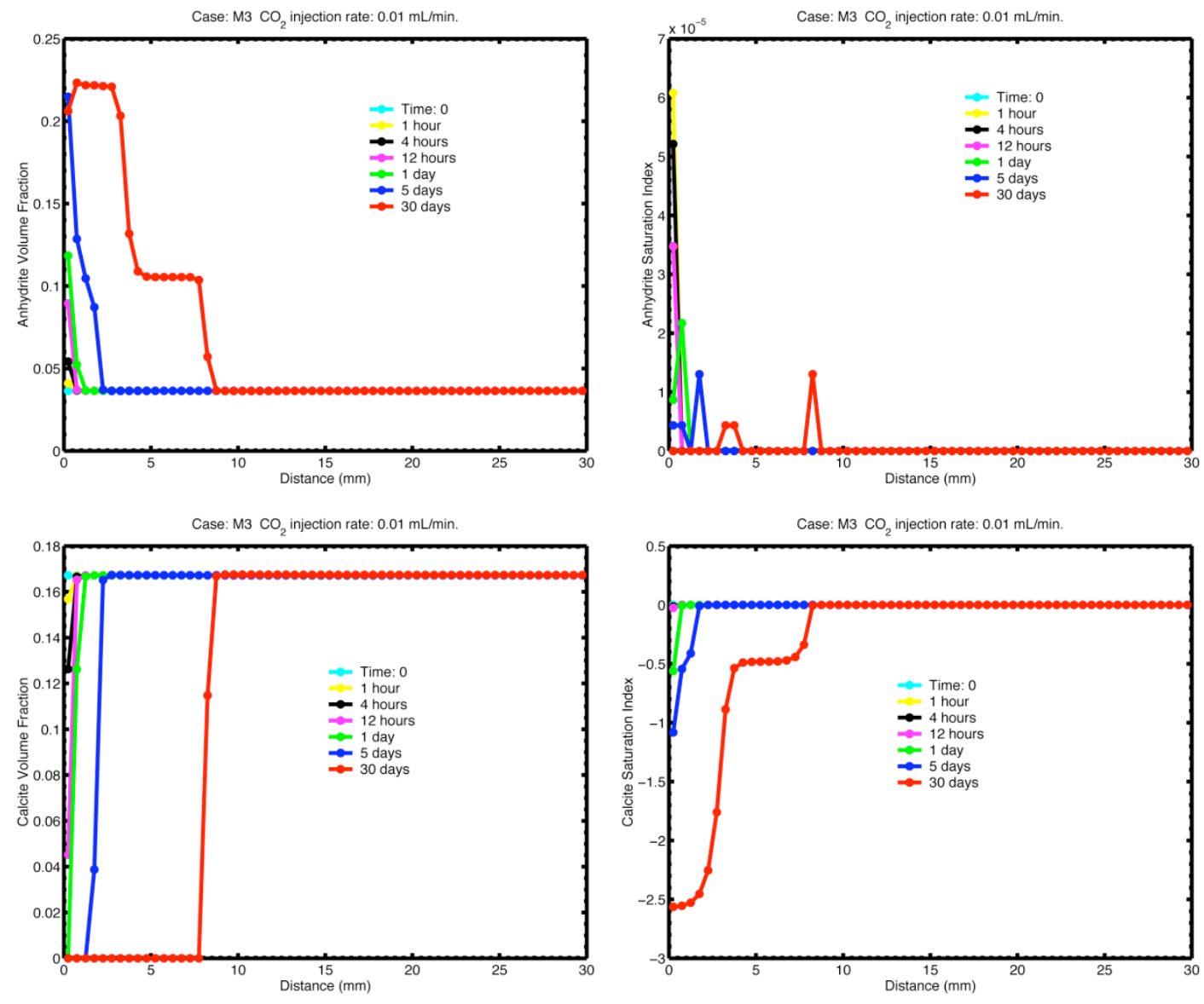
Figure 1. Simulations results for reaction of $\mathrm{CO}_{2}$ rich brine with $\mathrm{M} 3$ core with a flow rate $=0.01 \mathrm{ml} / \mathrm{min}$ plotted as a function of volume $\%$ anhydrite, calcite, dolomite, and porosity, as well as anhydrite, calcite, and dolomite saturation, and $\mathrm{pH}$ (see text for details).
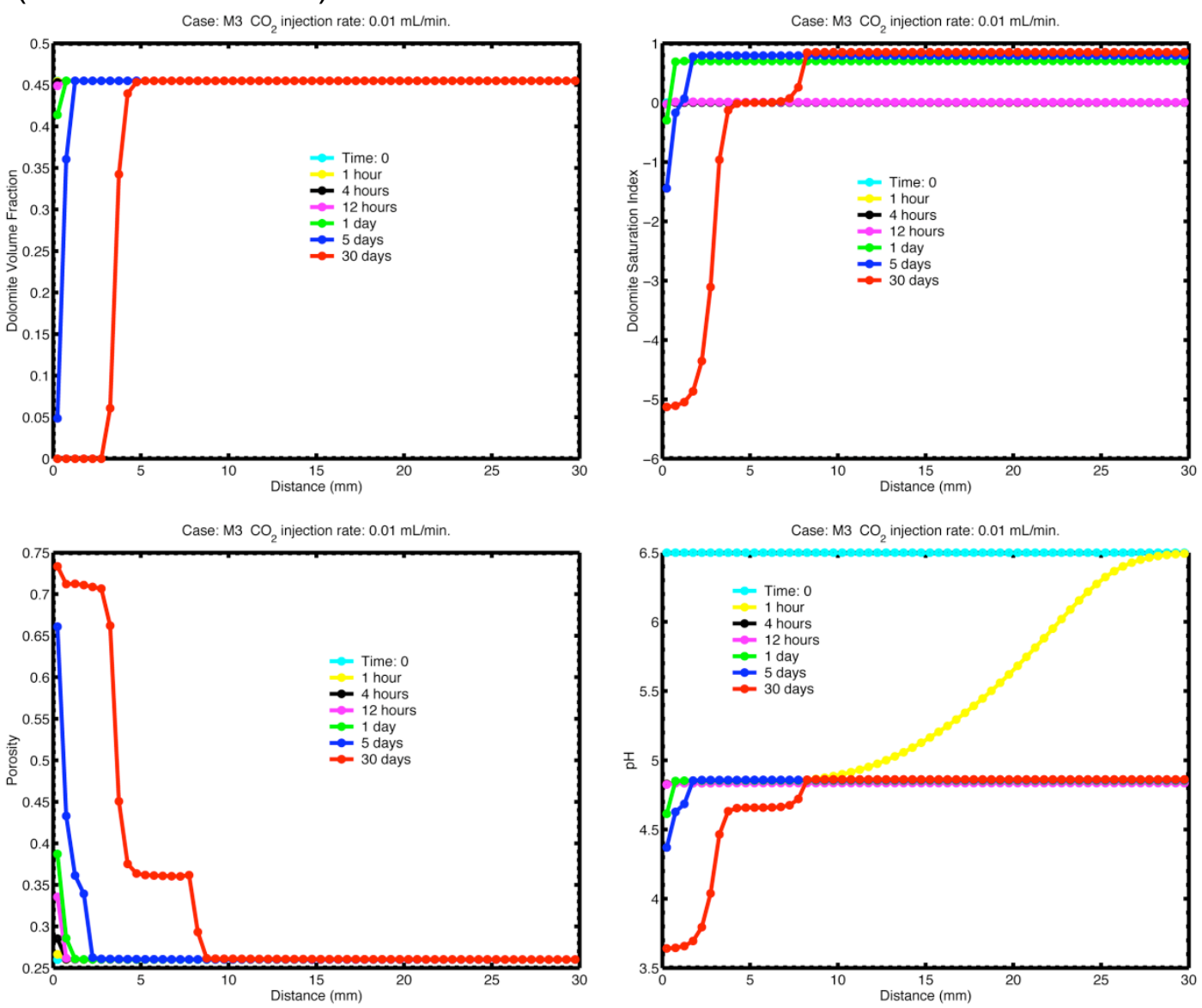

Figure 1 (continued).

Flow Rate $0.1 \mathrm{ml} / \mathrm{min}$. As expected, increasing the flow rate increases the area of enhanced porosity because more carbonate dissolution is required to neutralize the larger volume of acid brine that is passed through the core. Reaction of the Midale Marly flow unit for one day results in an increase in the porosity from its initial value of $26 \%$ to $50 \%$ at the inlet. Porosity evolution over distance is from calcite dissolution (up to $17 \mathrm{vol} \%$ ), dolomite dissolution (up to 18 $\mathrm{vol} \%$ ), and anhydrite precipitation (up to $11 \mathrm{vol} \%$ ). Beyond $4.5 \mathrm{~mm}$ of the inlet no change in porosity ocurrs because pore fluids are saturated with respect to calcite and anhydrite and supersaturated with respect to dolomite (dolomite is not allowed to precipitate in the model) as the fluid moves along the length of the core. The final acidity of the brine is near $\mathrm{pH} 4.8$ and is buffered by calcite saturation.

Increasing the reaction time to five days further enhances porosity. Porosity increases from its initial value of $26 \%$ to $72 \%$ at the inlet. Enhanced porosity is due to calcite dissolution (up to $17 \mathrm{vol} \%$ ), dolomite dissolution (up to 
$45 \mathrm{vol} \%$ ), and anhydrite precipitation (up to $19 \mathrm{vol} \%$ ). No change in porosity occurs beyond $15 \mathrm{~mm}$ of the inlet, because pore fluids are saturated with respect to calcite and anhydrite and supersaturated with respect to dolomite (dolomite is not allowed to precipitate in the model) as the fluid moves along the length of the core. The final acidity of the brine is near $\mathrm{pH} 4.8$ and is buffered by calcite saturation. Extending the reaction out to 30 days yields significant changes in porosity that may compromise the integrity of the core during the experiment.
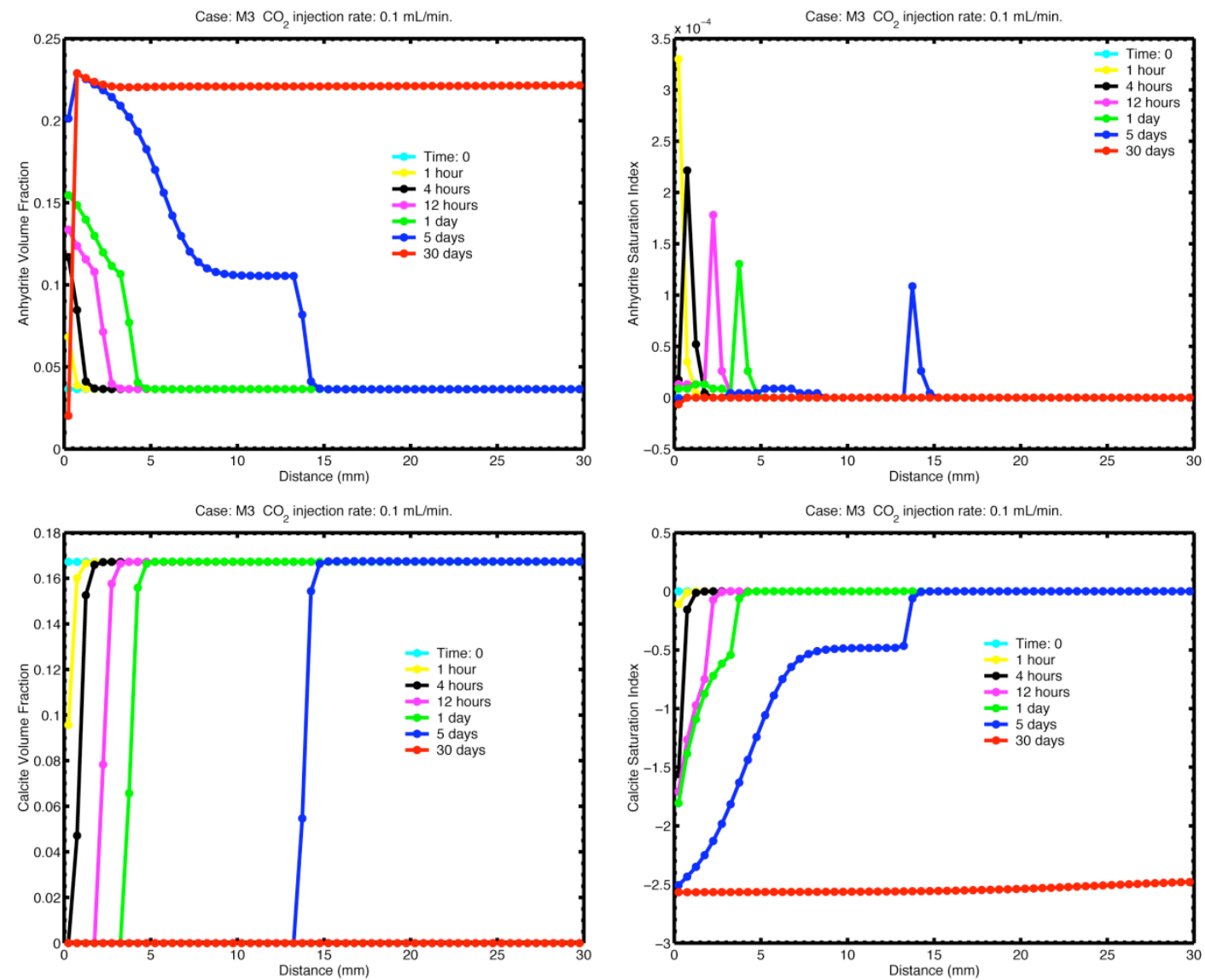

Figure 2. Simulations results for reaction of $\mathrm{CO}_{2}$ rich brine with $\mathrm{M} 3$ core with a flow rate $=0.1 \mathrm{ml} / \mathrm{min}$ plotted as a function of volume $\%$ anhydrite, calcite, dolomite, and porosity, as well as anhydrite, calcite, and dolomite saturation, and $\mathrm{pH}$ (see text for details). 

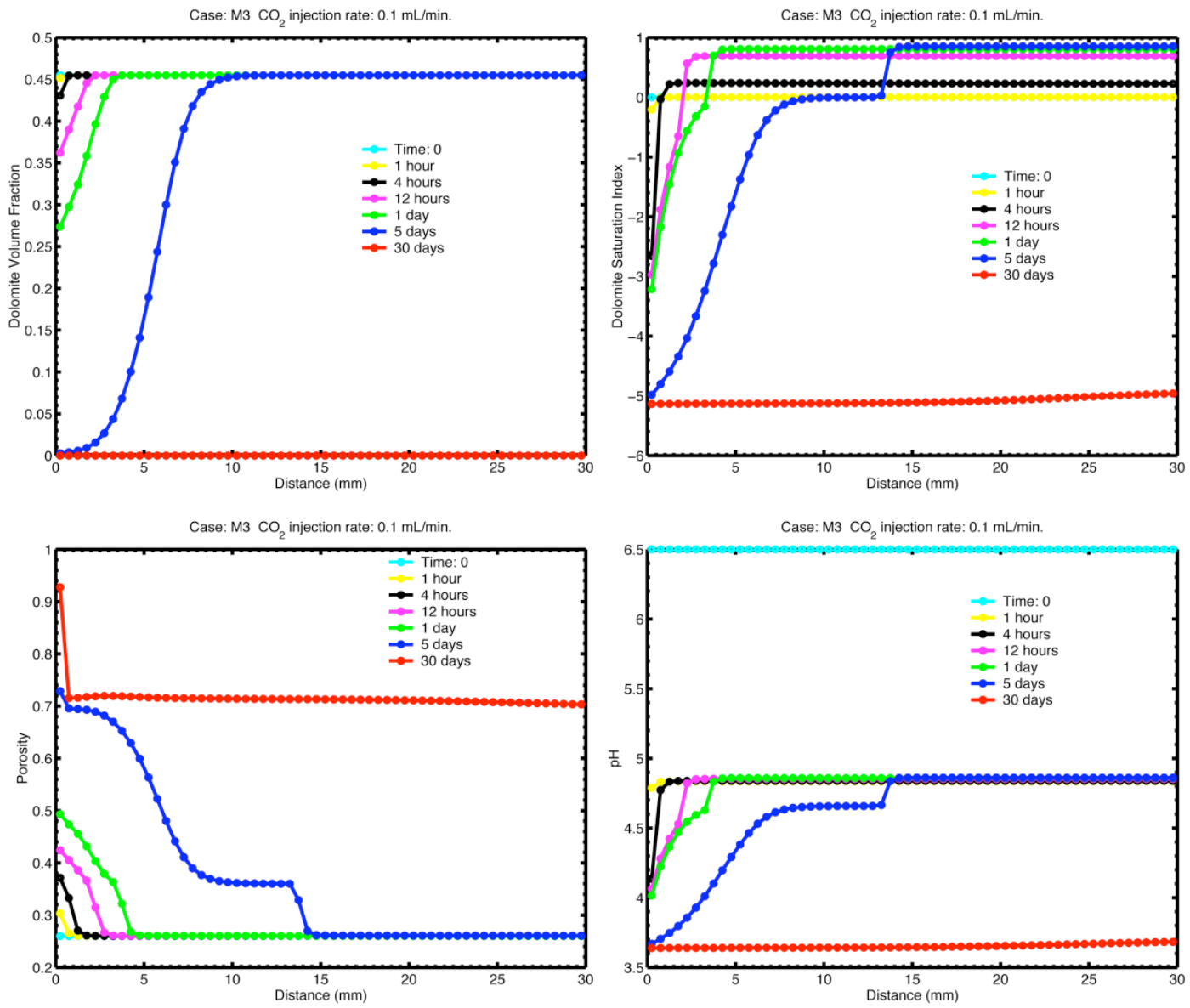

Figure 2 (continued).

\section{Midale Vuggy Intershoal (V1)}

Midale Vuggy Intershoal flow unit differs from the Midale Marly flow unit in both its composition and its initial porosity. The Midale Vuggy Intershoal mineralogy is dominated by calcite $(75 \mathrm{vol} \%)$ with lesser amounts of dolomite (10 vol \%), where as the Marly flow unit is dominated by dolomite (45 vol \%) with lesser amounts of calcite $(17 \mathrm{vol} \%)$. The $\mathrm{V} 1$ flow unit has less than half the initial porosity of M3.

Flow Rate $0.01 \mathrm{ml} / \mathrm{min}$. Reaction of the Midale Vuggy Intershoal flow unit for one day results in an increase in the porosity from its initial value of $10 \%$ to $22 \%$ at the inlet. Porosity evolution over distance is from calcite dissolution (up to 21 vol $\%$ ), dolomite (up to $1 \%$ ), and anhydrite precipitation (up to 9 vol \%). Beyond 1 $\mathrm{mm}$ of the inlet no change in porosity occurs because pore fluids are saturated with respect to calcite, anhydrite and dolomite as the fluid moves along the length of the core. The steady-state acidity of the brine is near $\mathrm{pH} 4.8$ and is buffered by calcite saturation.

Increasing the reaction time to five days creates a larger area of enhanced porosity. Porosity increases from its initial value of $10 \%$ to $62 \%$ at the inlet. 
Enhanced porosity results from calcite dissolution (up to 76\%) and dolomite dissolution (up to $10 \mathrm{vol} \%$ ), and anhydrite precipitation (up to $34 \%$ ). Within 2 $\mathrm{mm}$ of the inlet no change in porosity occurs, because pore fluids are saturated with respect to calcite, anhydrite and dolomite as the fluid moves along the length of the core. The final acidity of the brine is near $\mathrm{pH} 4.8$ and is buffered by calcite saturation. Extending the reaction out to 30 days yields significant changes in porosity that may compromise the integrity of the core during the experiment.
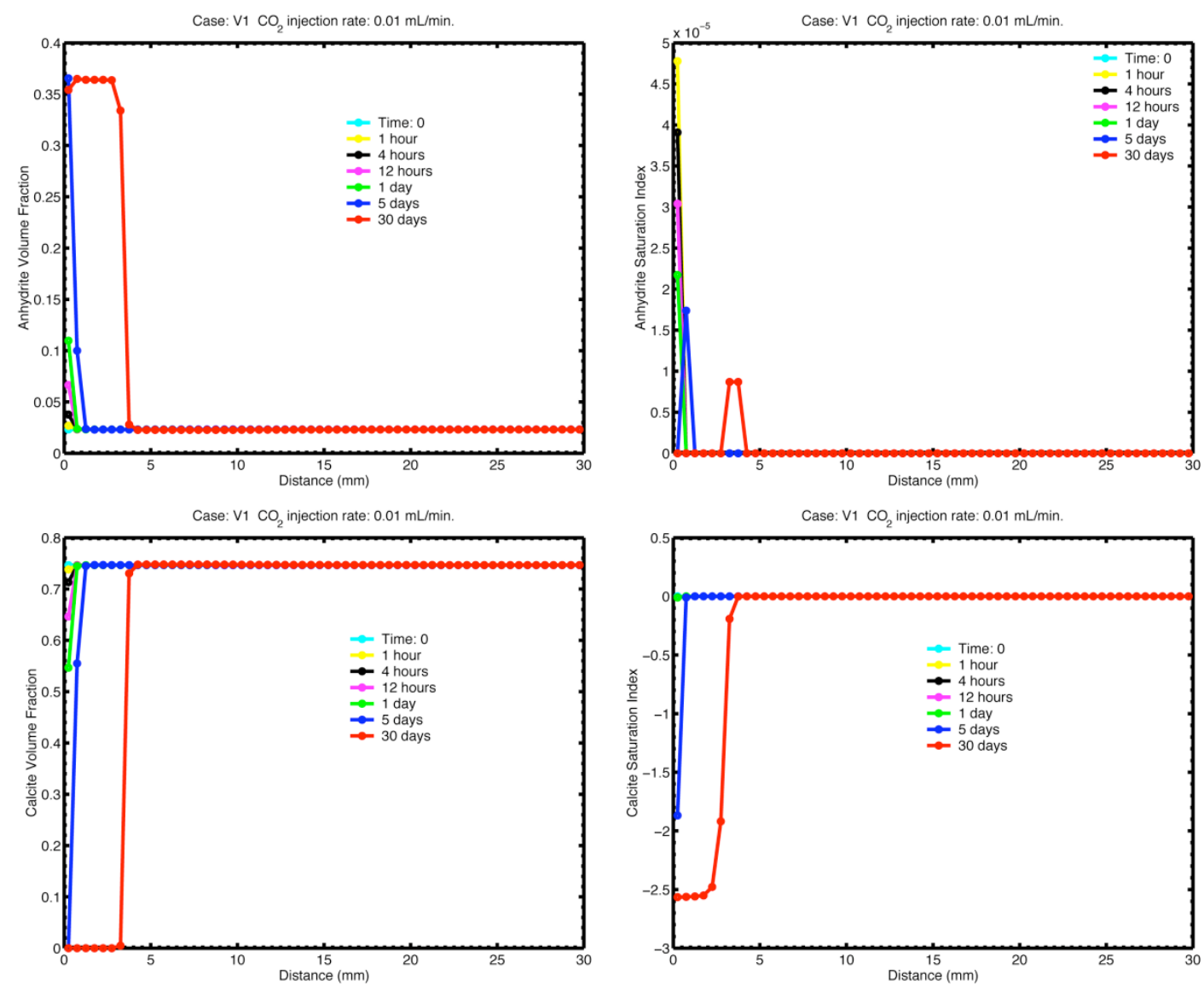

Figure 3. Simulations results for reaction of $\mathrm{CO}_{2}$ rich brine with $\mathrm{V} 1$ core with a flow rate $=0.01 \mathrm{ml} / \mathrm{min}$ plotted as a function of volume $\%$ anhydrite, calcite, dolomite, and porosity, as well as anhydrite, calcite, and dolomite saturation, and $\mathrm{pH}$ (see text for details). 

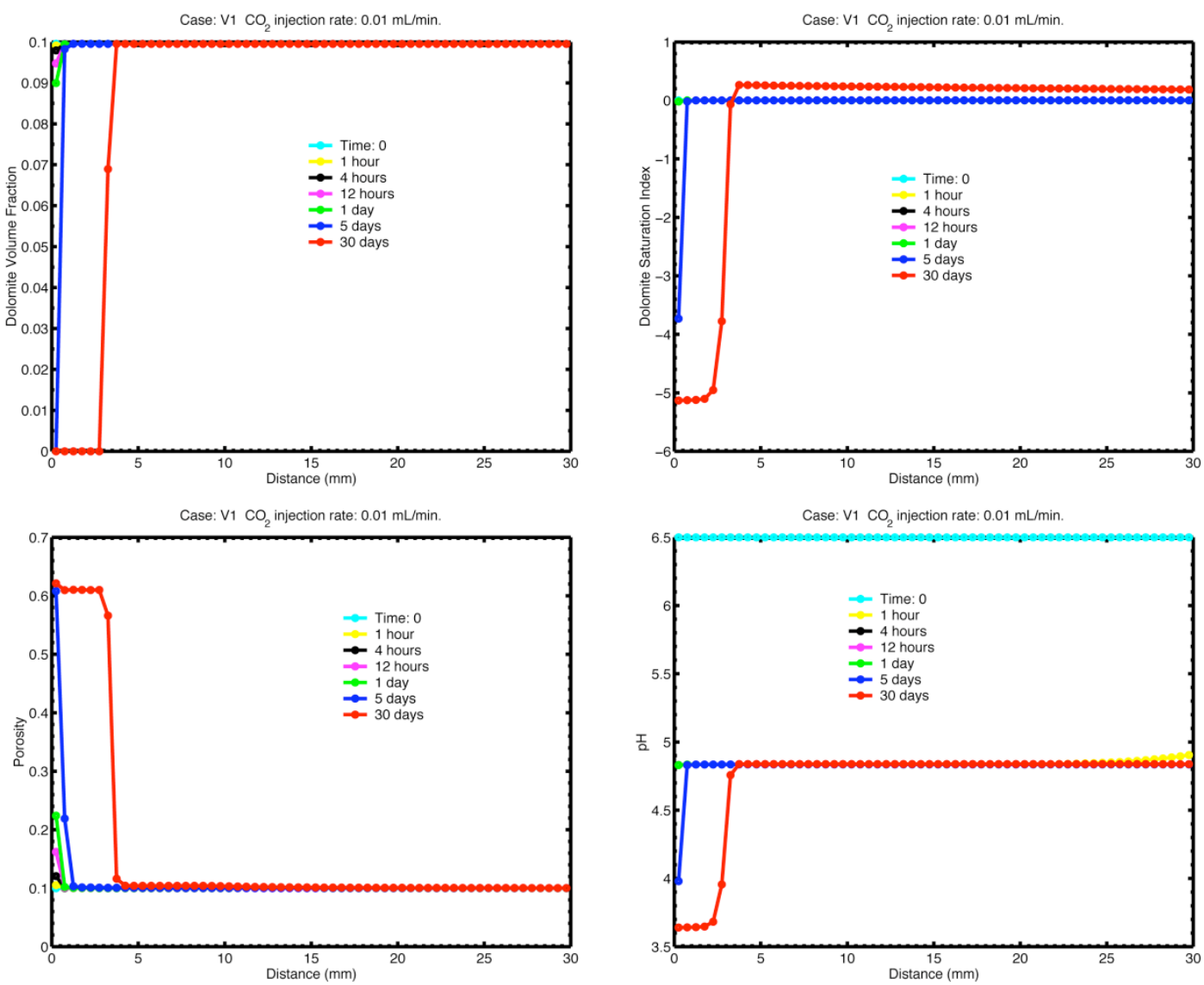

Figure 3 (continued).

Flow Rate $0.1 \mathrm{ml} / \mathrm{min}$. As expected, increasing the flow rate increases the area of enhanced porosity because more carbonate dissolution is required to neutralize the larger volume of acid brine that is passed through the core. Reaction of the Midale Vuggy Intershoal flow unit for one day results in an increase in the porosity from its initial value of $10 \%$ to $59 \%$ at the inlet. Porosity evolution over distance is from calcite dissolution (up to $76 \mathrm{vol} \%$ ) and dolomite dissolution (up to $9 \mathrm{vol} \%$ ), and anhydrite precipitation (up to $36 \mathrm{vol} \%$ ). Beyond $3 \mathrm{~mm}$ of the inlet no change in porosity occurs because pore fluids are saturated with respect to calcite, anhydrite and dolomite as the fluid moves along the length of the core. The final acidity of the brine is near $\mathrm{pH} 4.8$ and is buffered by calcite saturation.

Increasing the reaction time to five days further enhances porosity. Porosity increases from its initial value of $10 \%$ to $62 \%$ at the inlet. Porosity evolution over distance is from calcite dissolution (up to $75 \mathrm{vol} \%$ ), dolomite dissolution (up to $10 \mathrm{vol} \%$ ), and anhydrite precipitation (up to $36 \mathrm{vol} \%$ ). No change in porosity beyond $7 \mathrm{~mm}$ because pore fluids are saturated with respect to calcite, anhydrite and dolomite as the fluid moves along the length of the core. The final acidity of the brine is near $\mathrm{pH} 4.8$ and is buffered by calcite saturation. Extending the reaction out to 30 days yields significant changes in porosity that may compromise the integrity of the core during the experiment. 

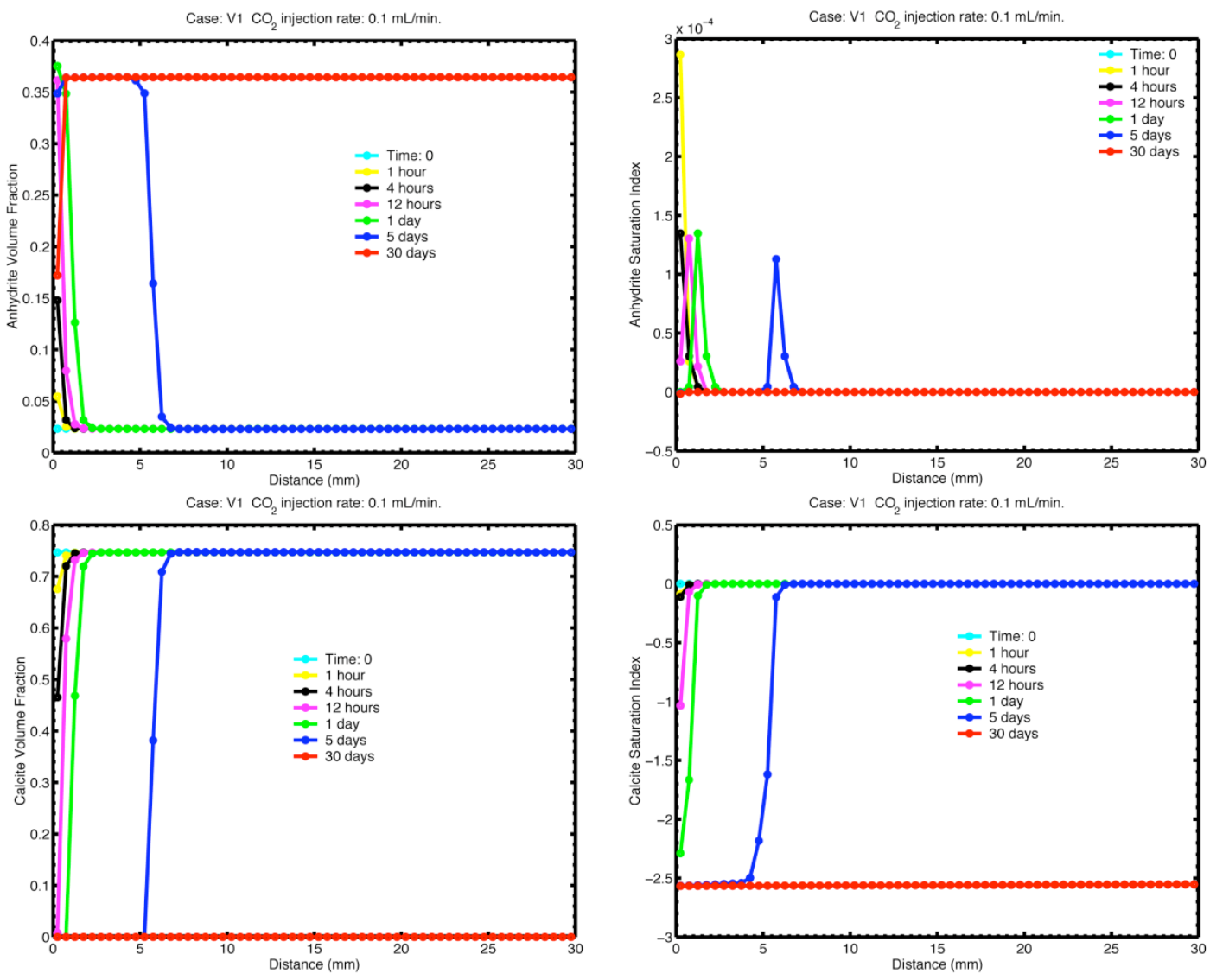

Figure 4. Simulations results for reaction of $\mathrm{CO}_{2}$ rich brine with $\mathrm{V} 1$ core with a flow rate $=0.1 \mathrm{ml} / \mathrm{min}$ plotted as a function of volume $\%$ anhydrite, calcite, dolomite, and porosity, as well as anhydrite, calcite, and dolomite saturation, and $\mathrm{pH}$ (see text for details). 

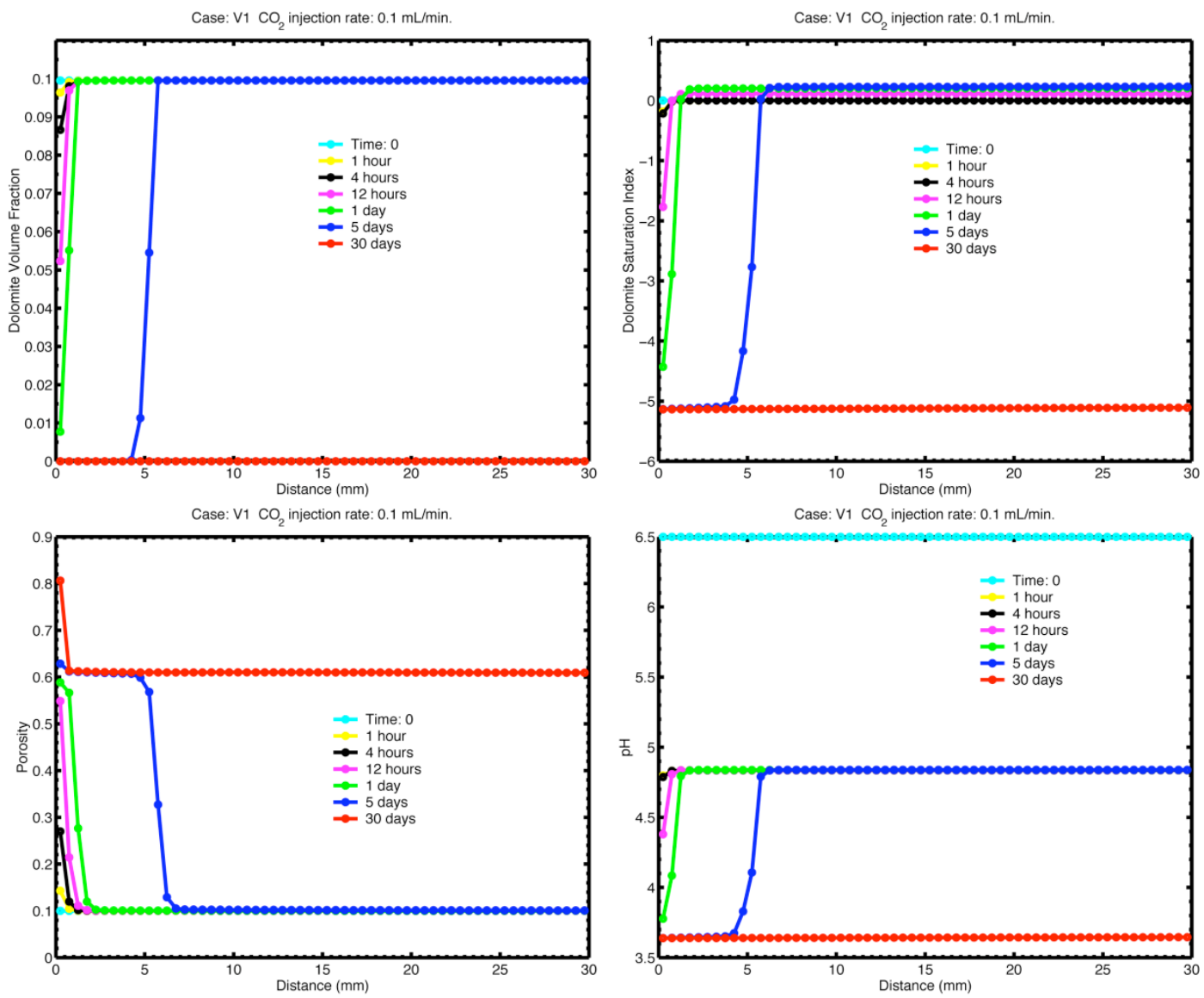

Figure 4. (continued)

\section{Midale Vuggy Shoal (V6)}

Midale Vuggy Shoal (V6) and Intershoal (V1) flow units have very similar composition with significant amounts of calcite and lesser amounts of dolomite and anhydrite. The primary differences between these two flow units are that the $\mathrm{V} 6$ unit is over sixteen times more permeable than $\mathrm{V} 1$, and the $\mathrm{V} 6$ unit has $50 \%$ more porosity than $\mathrm{V} 1$ (Table 1 ).

Flow Rate $0.01 \mathrm{ml} / \mathrm{min}$. Reaction of the Midale Vuggy Shoal flow unit for one day results in an increase in the porosity from its initial value of $15 \%$ to $28 \%$ at the inlet. Enhanced porosity results from calcite dissolution (up to $22 \mathrm{vol} \%$ ), dolomite dissolution (up to 1\%), and anhydrite precipitation (up to 9 vol \%). Beyond $1 \mathrm{~mm}$ of the inlet no change in porosity occurs, because pore fluids are saturated with respect to calcite, anhydrite and dolomite as the fluid moves along the length of the core. The final acidity of the brine is near $\mathrm{pH} 4.8$ and is buffered by calcite saturation.

Increasing the reaction time to five days creates a larger area of enhanced porosity. Porosity increases from its initial value of $15 \%$ to $58 \%$ at the inlet. Enhanced porosity results from calcite dissolution (up to $60 \mathrm{vol} \%$ ), dolomite dissolution (up to $12 \mathrm{vol} \%$ ) and anhydrite precipitation (up to $29 \mathrm{vol} \%$ ). Beyond $2 \mathrm{~mm}$ of the inlet no change in porosity occurs, because pore fluids are saturated 
with respect to calcite, anhydrite and dolomite as the fluid moves along the length of the core. The final acidity of the brine is near $\mathrm{pH} 4.8$ and is buffered by calcite saturation. Extending the reaction out to 30 days yields significant changes in porosity that may compromise the integrity of the core during the experiment.
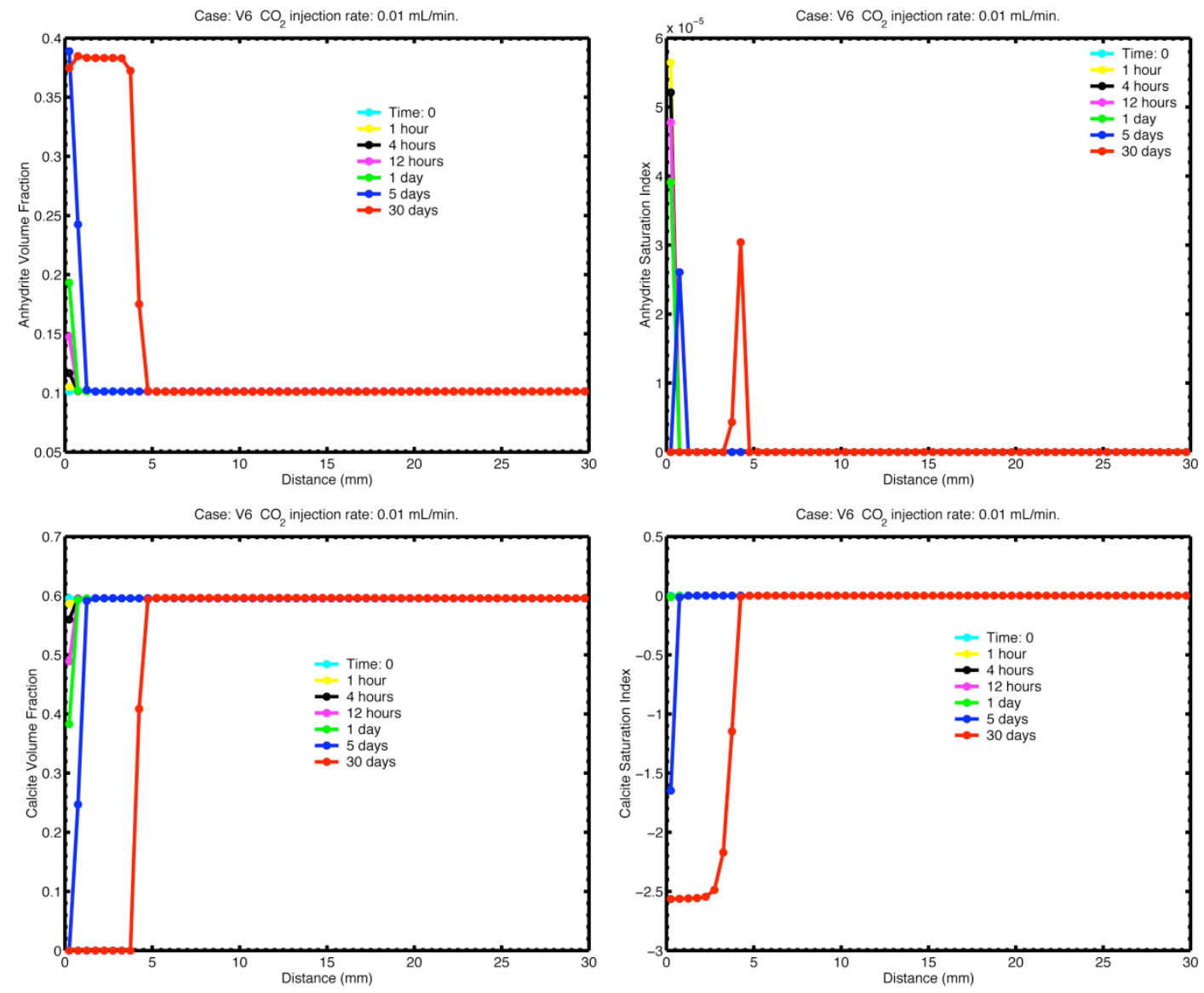

Figure 5. Simulations results for reaction of $\mathrm{CO}_{2}$ rich brine with $\mathrm{V} 6$ core with a flow rate $=0.01 \mathrm{ml} / \mathrm{min}$ plotted as a function of volume $\%$ anhydrite, calcite, dolomite, and porosity, as well as anhydrite, calcite, and dolomite saturation, and $\mathrm{pH}$ (see text for details). 

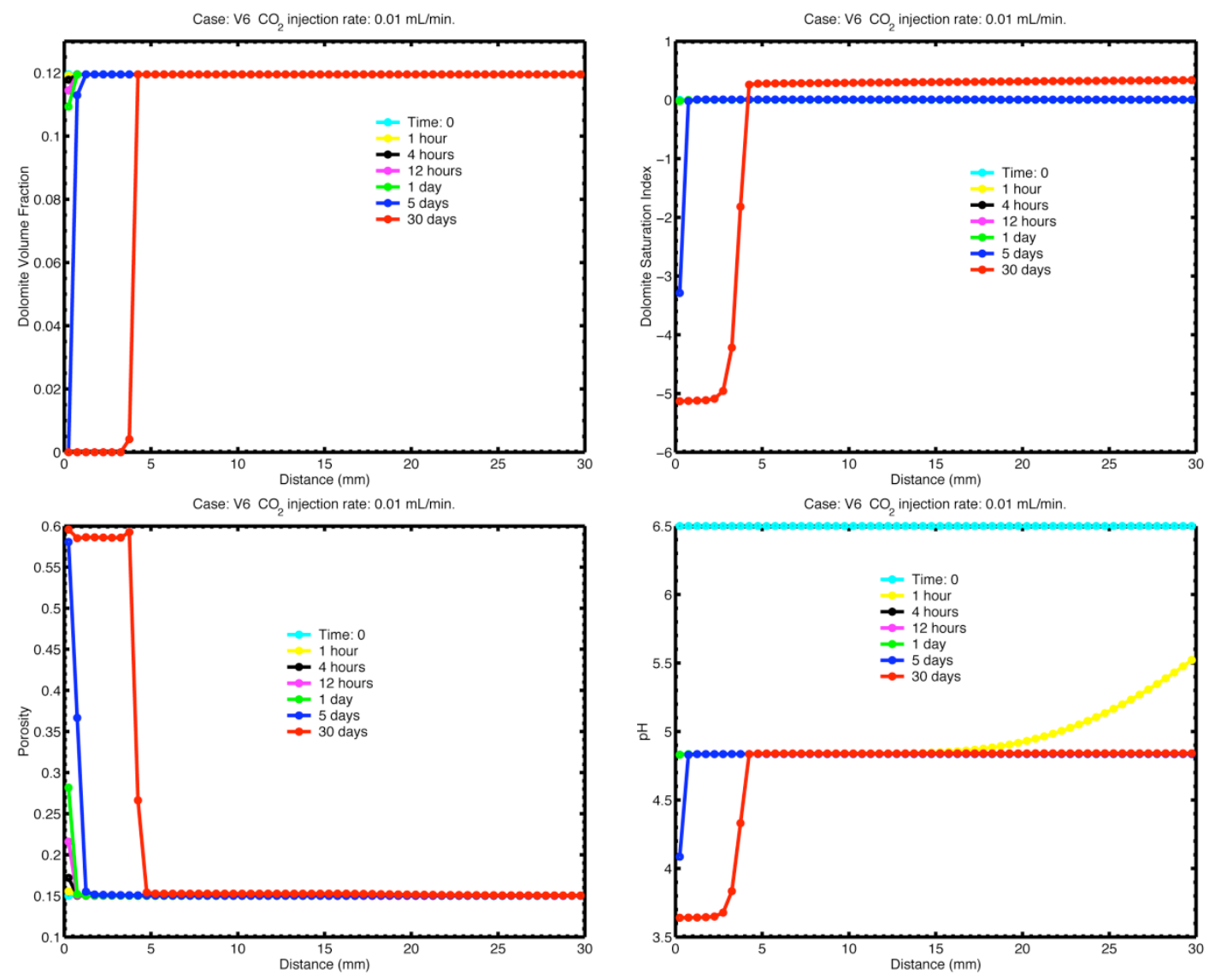

Figure 5 (continued)

Flow Rate $0.1 \mathrm{ml} / \mathrm{min}$. As expected, increasing the flow rate increases the area of enhanced porosity because more carbonate dissolution is required to neutralize the larger volume of acid brine that is passed through the core. Reaction of the Midale Vuggy Shoal flow unit for one day results in an increase in the porosity from its initial value of $15 \%$ to $56 \%$ at the inlet. Porosity evolution over distance is from calcite dissolution (up to $60 \mathrm{vol} \%$ ), dolomite dissolution (up to $11 \mathrm{vol} \%$ ), and anhydrite precipitation (up to $29 \mathrm{vol} \%$ ). Beyond $3 \mathrm{~mm}$ of the inlet no change in porosity occurs, because pore fluids are saturated with respect to calcite, anhydrite and dolomite as the fluid moves along the length of the core. The final acidity of the brine is near $\mathrm{pH} 4.8$ and is buffered by calcite saturation. Increasing the reaction time to five days further enhances porosity. Porosity increases from its initial value of $10 \%$ to $58 \%$ at the inlet. Porosity evolution over distance is from calcite dissolution (up to $60 \mathrm{vol} \%$ ), dolomite dissolution (up to $12 \mathrm{vol} \%$ ), and anhydrite precipitation (up to $28 \mathrm{vol} \%$ ). Beyond $8 \mathrm{~mm}$ of the inlet no change in porosity occurs, because pore fluids are saturated with respect to calcite, anhydrite and dolomite as the fluid moves along the length of the core. The final acidity of the brine is near $\mathrm{pH} 4.8$ and is buffered by calcite saturation. Extending the reaction out to 30 days yields significant changes in porosity that may compromise the integrity of the core during the experiment. 

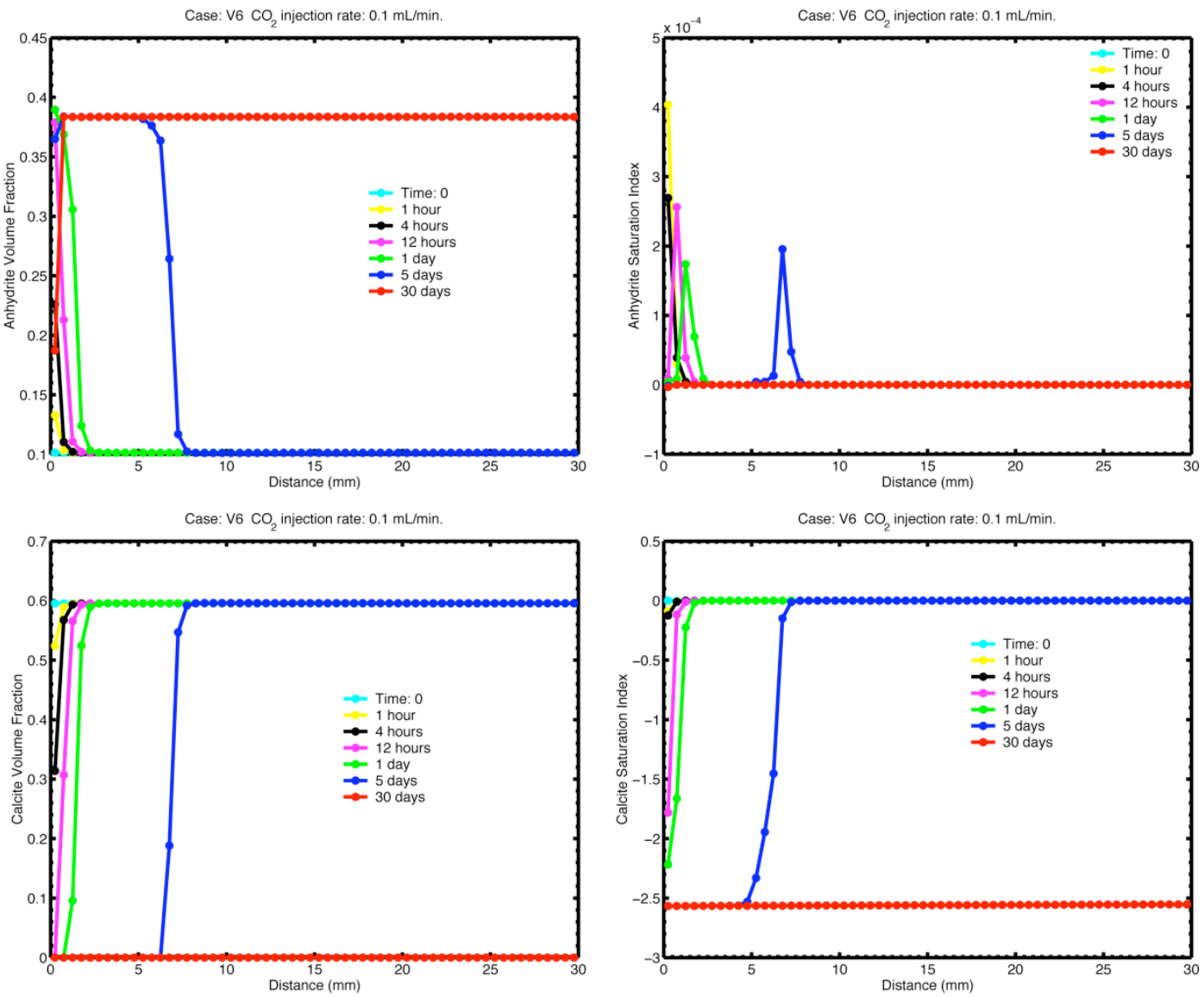

Figure 6. Simulations results for reaction of $\mathrm{CO}_{2}$ rich brine with $\mathrm{V} 6$ core with a flow rate $=0.1 \mathrm{ml} / \mathrm{min}$ plotted as a function of volume $\%$ anhydrite, calcite, dolomite, and porosity, as well as anhydrite, calcite, and dolomite saturation, and $\mathrm{pH}$ (see text for details). 

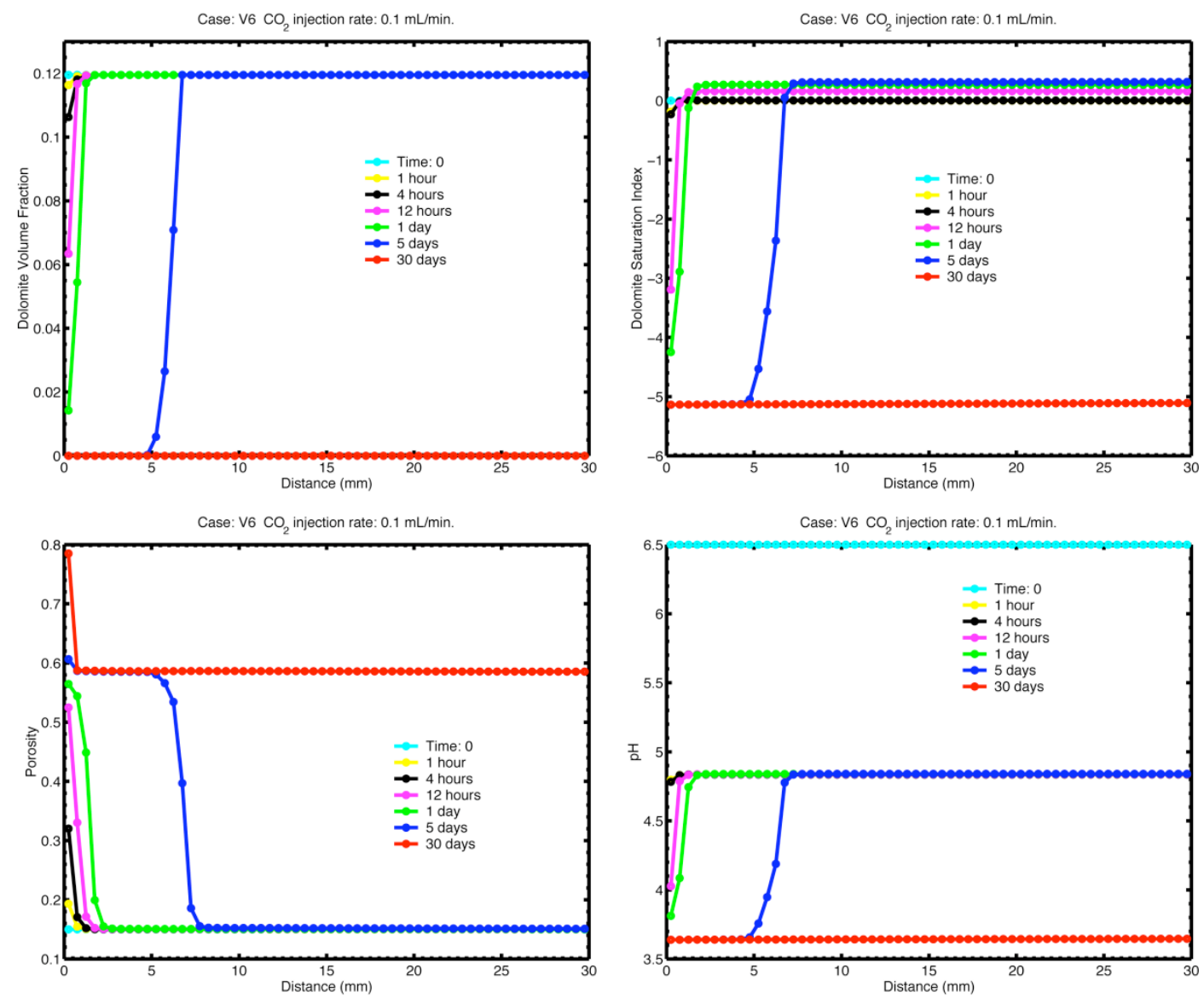

Figure 6 (continued)

\section{Comparison with other studies}

In this section we compare the simulation results reported here to experimental and modeling studies. Our simulation results suggest significant changes in porosity over a very short time period when acid, $\mathrm{CO}_{2}$-rich brines react with carbonate geology. Luquot and Gouze (2009) documented a 4\% porosity increase over a 2-hour experiment where input solution compositions were far from equilibrium (Table 2). Had the experiments run for a longer period of time, we would expect a much larger change in the porosity. In much longer experiments from 25 days to 6 months, Le Guen et al (2007) measured 2 to $3 \%$ changes in porosity where verical and axial stress was independently controlled. The researchers used a slow flow rate, larger core, and $\mathrm{CO}_{2}$-rich and $\mathrm{Ca}$-poor solutions. It is possible that some combination of an applied strain rate, low flow rate, and slower reaction kinetics could account for the discrepancy between the experimental results and the simulations reported here.

Comparison of simulations for laboratory experiments and much larger field conditions raises some concerns on the ability to scale experimental studies to the reservoir environment. In previous work, we simulated the impact of $\mathrm{CO}_{2}$ storage for the Ordos Basin, using a very similar geochemical model China (Hao et al., 2009). Changes in reservoir porosity and permeability are expected to be minimal during injection and storage, because there is minimal mineral 
dissolution and precipitation of the carbonate geology. Figure 7 shows the percentage of the original amount of calcite and dolomite dissolved over the 20year simulation near the injection well at the base of the dolostone reservoir. The amount of dolomite dissolved is negligible and is on the order of the uncertainty in the numerical simulations. The amount of calcite dissolution is also quite small. Dissolution of about $1.5 \%$ of the initial volume of calcite in the rock (only $1 \%$ ) increases the porosity by $0.015 \%$. Some of calcium dissolved from calcite reacts with dissolved sulfate and forms anhydrite. Again the absolute amount is too small to impact porosity and permeability.

The discrepancy between the porosity changes predicted for the core flood experiment and the $\mathrm{CO}_{2}$ storage in a dolostone formation raises at least two concerns. Firstly, does the much larger grid size for the field scale simulation provide a larger buffering capacity for $\mathrm{CO}_{2}$ rich fluid? Secondly, does the experiment in which the $\mathrm{CO}_{2}$-rich fluid continually reacts with the carbonate geology an appropriate model for $\mathrm{CO}_{2}$ the injection within the reservoir? In Ordos Basin simulation, supercritical $\mathrm{CO}_{2}$ is injected into the reservoir at defined flux that is spread out over the thickness of the storage unit at a flux limited by low permeability of the rocks. Once injected rock heterogeneity (primarily porosity and permeability) and low $\mathrm{CO}_{2}$ density permits the $\mathrm{CO}_{2}$ to move away from the injection source. Particularly, under high injection pressure-buildup supercritical $\mathrm{CO}_{2}$ tends to displace brine with dissolved $\mathrm{CO}_{2}$ away from injection wells, which may discourage mineral dissolution/precipitation processes over there. Additionally for a lower permeable reservoir $\mathrm{CO}_{2}$ injection rates are controlled, and longer or multiple injection wells are used in order to avoid higher over-pressure and mechanical damage to the reservoir. This will further help disperse $\mathrm{CO}_{2}$ over a large area of the reservoir, and result in relatively lower $\mathrm{CO}_{2}$ injection rates per unit of volume of reservoir. Therefore it may take much longer time for $\mathrm{CO}_{2}$ injection to cause significant porosity changes due to mineral reactions in the reservoir. In contrast with 2-D or 3-D reservoir-scale modeling the simulations performed in this study are limited to one-dimensional, and the continuous $\mathrm{CO}_{2}$ flooding concentrates on a very small core sample. The difference in terms of problem scale and flow conditions may explain the discrepancy between the porosity change predictions from lab-scale and reservoir-scale simulations, however, further simulations needed in order to address this concern from both physical and numerical point of view.

\section{Concluding Comments on Experimental Design}

Design of a meaningful experiment requires that the extent of reaction be measured by changes in inlet and outlet solution composition and changes in the porosity as measured by $\mathrm{x}$-ray micro-tomography. The simulations suggest that reaction of the cores with formation brine equilibrated with supercritical $\mathrm{CO}_{2}$ at 14.7 M Pascals and $60^{\circ} \mathrm{C}$ should yield measurable changes in both chemistry and porosity and permeability with a flow rate equal to $0.01 \mathrm{ml} / \mathrm{min}$ within a 24hour period. Shorter reaction periods or lower flow rates may be desirable as predicted porosity changes can be quite high at inlet where the acid solution first 
reacts with the core mineralogy. Additional scenarios will be considered to best study field conditions experimentally. Specifically, using supercritical $\mathrm{CO}_{2}$ to displace ambient brine and lower flow rates with varying $\mathrm{pCO}_{2}$ representative of a referenced time and place for the $\mathrm{CO}_{2}$ operations at Weyburn.

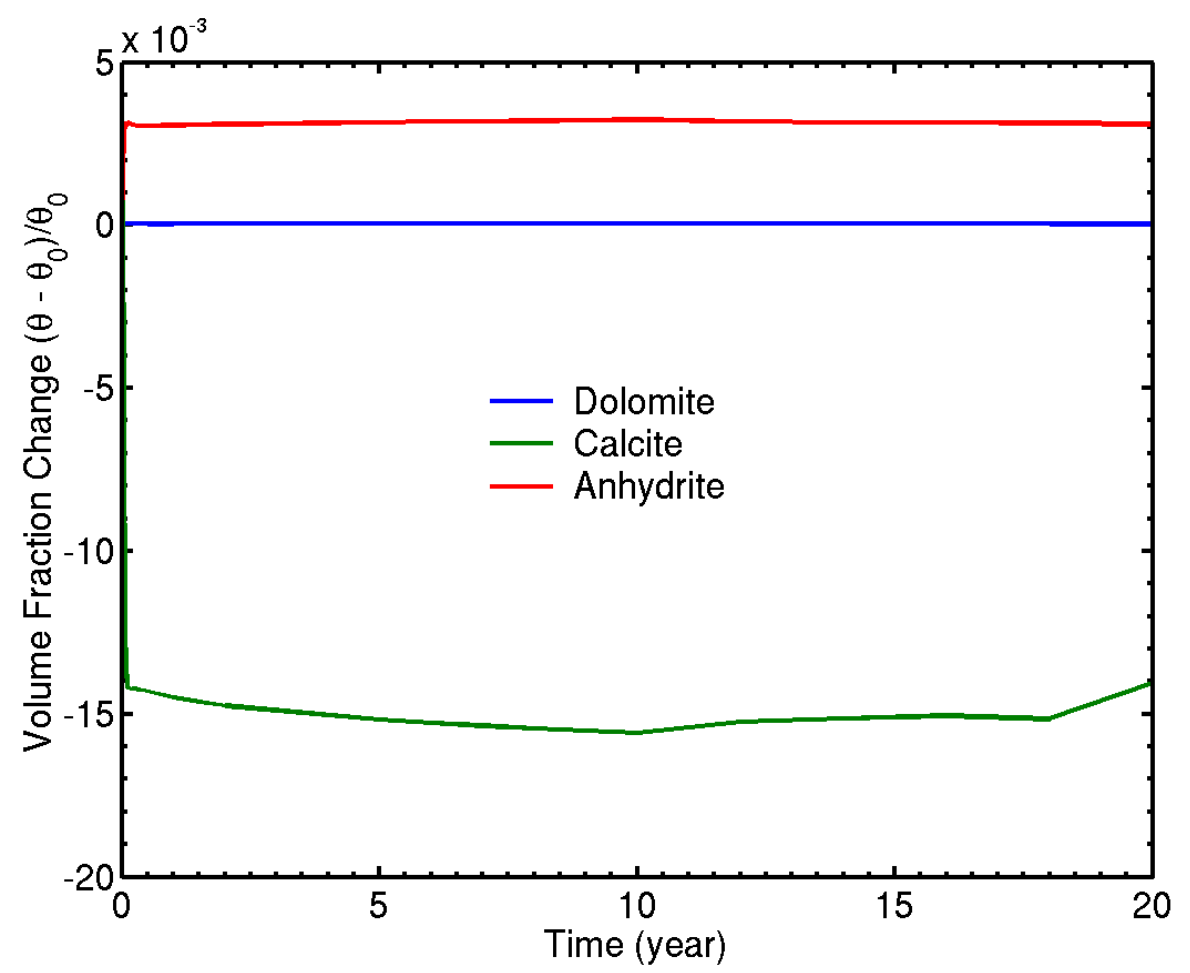

Figure 7. Change in mineral volume fraction of dolomite, calcite, and anhydrite caused by $\mathrm{CO}_{2}$ injection into a carbonate rock with low permeability. Injection spans from 0 to 10 years. The location is near the injection well which experiences the most acid conditions over the run (Hao et al., 2009).

\section{References}

Bailey N.J.L., Jobson A.M., Rogers M.A. (1973) Bacterial degradation of crude oil: comparison of field and experimental data. Chemical Geology, 11, 203-221.

Bailey N.J.L., Krouse H.R., Evans C.R., Rogers M.A. (1973) Alteration of crude oil by waters and bacteria - evidence from geochemical and isotope studies. AAPG Bulletin, 57, 1276-1290.

Bachu S., Beneenion D. B., Pooladi-Darvish M., Hong H. (2009) Factors affecting the chromatographic partitioning of $\mathrm{CO} 2$ and $\mathrm{H} 2 \mathrm{~S}$ injected into a water-saturated porous medium. Energy Procedia, 1, 3165-3172. 
Blum A.E., Stillings L.L. (1995) Feldspar dissolution kinetics. In CHEMICAL WEATHERING RATES OF SILICATE MINERALS, REVIEWS IN MINERALOGY, 31, 291-351.

Buscheck TA, Glascoe LG, Lee KH, Gansemer J, Sun Y, Mansoor K (2003) Validation of the Multiscale Thermohydrologic Model used for analysis of a proposed repository at Yucca Mountain. J. Contaminant Hydrology, 62-3, 421440.

Carroll, S., Hao, Y, Aines, R: (2009) Geochemical detection of $\mathrm{CO}_{2}$ in dilute aquifers. Geochemical Transactions, 10:4 .

Durocher K, Hutcheon I, Shevalier M., Mayer B., Gunter B., Perkins E., Bloch J. (2003) IEA Weyburn $\mathrm{CO}_{2}$ Monitoring and Storage Project, Subtask 3.1 Reservoir (Baseline Mineralogy Final Report.

Emberley S., Hutcheon I., Shevalier M., Durocher K., Mayer B., Gunter W.D., Perkins E.H. (2005) Monitoring of fluid-rock interaction and CO2 stroage through produced fluid sampling at the Weyburn CO2-injection enhanced oil recovery site, Saskatchewan, Canada. Applied Geochemistry, 20, 1131-1157.

Gale, J. (2009) Impure thoughts. International J. of Greenhouse Gas Control, 3, $1-2$.

Glassley WE, Nitao JJ, Grant CW (2003) Three-dimensional spatial variability of chemical properties around a monitored waste emplacement tunnel. J.

Contaminant Hydrology, 62-63, 495-507.

Huxley, D. (2006) Dakota Gasification Company CO2 sequestration verification project - a case study of greenhouse gas reduction verification and marketing. Fuel Processing Technology 87, 179-183.

Jacquement N., Le Gallo y., Estublier A., Lachet V., von Dalwigk I., Yan J., Azaroual M., Audigane P. (2009) CO2 streams containing associated components - a review of the thermodynamic and geochemical properties and assessment of some reactive transport codes. Energy Procedia, 1, 3739-3746.

Johnson, J. W., Oelkers, E. H., and Helgeson, H. C (1992) SUPCRT92: A software package for calculating the standard molal thermodynamic properties of minerals, gases, aqueous species, and reactions from 1 to 5000 bars and $0^{\circ}$ to $1000^{\circ} \mathrm{C}$. Computers and Geosciences, 18, 899-947.

Johnson, J. W., Nitao, J. J., Knauss, K. G. (2004) Reactive transport modeling of $\mathrm{CO}_{2}$ storage in saline aquifers to elucidate fundamental processes, trapping mechanisms and sequestration partitioning. In: Geological Storage of Carbon Dioxide. Edited by SJ Baines, RH Worden. Geological 
Society, London, Special Publications, 223, 107-128

Johnson JW, Nitao JJ, Morris JP (2005) Reactive transport modeling of cap-rock integrity during natural and engineered $\mathrm{CO}_{2}$ storage. In Carbon Dioxide Capture for Storage in Deep Geologic Formations. Edited by D. C. Thomas and S. M. Benson, 2: 787-813.

Knauss, K.G., Johnson, J. W., Steefel, C. I. (2005) Evaluation of the impact of $\mathrm{CO} 2$, co-contaminent gas, aqueous fluid and reservoir rock interactions on the geologic sequestration of CO2. Chemical Geology, 217, 339-350.

Le Guen Y., Renard F., Hellmann R., Brosse E., Collombet M., Tisserand D., Gratier J.-P. (2007) Enhanced deformation of limestone and sandstone in the presence of high PCO2 fluids. J. Geophysical Research, 112, B05421, doi:10:1029/2006JB004637.

Luquot L., Gouze P. (2009) Emperimental determination of porosity and permeability changes induced by injection of $\mathrm{CO} 2$ into carbonate rocks. Chemical Geology, doi:10.1016/jchemgeo.2009.03.028.

Palandri, J.L., Kharaka, Y.K (2004) A Compilation of Rate Parameters of Water-Mineral Interaction Kinetics for Application to Geochemical Modeling. Open File Report 2004-1068, U.S. Department of the Interior, U.S. Geological Survey, $64 \mathrm{p}$

Perez R. J., Shevalier M., Hutcheon I., Mayer B. (2006) A model ofr partitioning gases among brines and hydrocarbons in oil reservoirs: Examples from the IEAGHG Weyburn CO2 monitoring and storage project, Saskatchewan, Canada. J. of Geochemical Exploration, 89, 326-330.

Raistrick M., Mayer B., Shevalier M., Perez R. J., Hutcheon I., Perkins E., Gunter B. (2006) Using chemical and isotopic data to quantify ionic trapping of injected carbon dioxide in oil field brines. Environmental Science and Technology, 40, 6744-6749.

Schoonen M., Xu Y. (2004) The kinetics of hydrogen sulfide sequestration in sandstones. Water-Rock Interaction, Wanty \& Seal (eds).

Sorensen J. A., Holubnyak Y.I., Hawthorne S.B., Miller D.J., Eylands K., Steadman E.N., Harju J.A. (Laboratory and numerical modeling of geochemical reactions in a reservoir used for CO2 storage. Energy Procedia, 1, 3391-3398.

Wegelin A. (1984) Geology and reservoir properties of the Weyburn Field, Southeastern Saskatchewan. Oil and gas in Saskatchewan 1984, pp. 71-82. 
White D. J., Johnson J. W. (2009) Integrated geophysical and geochemical research programs of the IEA GHG Weyburn-Midale CO2 monitoring and storage project. Energy Procedia, 1, 2349-2356. 